\title{
DEVELOPMENT OF NIPA (Nypa fruticans) SAP CLOSED COLLECTION VESSEL
}

\author{
James Paul T. Madigal ${ }^{1 \bullet}$, Bethany Grace S. Calixto ${ }^{1, a}$, Michael Duldulao ${ }^{1, b}$, Thomas D. Ubiña $a^{1, c}$, \\ and Shirley C. Agrupis ${ }^{1, d}$ \\ ${ }^{1}$ Mariano Marcos State University, City of Batac, 2906 Ilocos Norte, Philippines \\ *Department of Biological Sciences, College of Arts and Sciences, Mariano Marcos State University, City \\ of Batac, 2906 Ilocos Norte Philippines \\ ${ }^{a b}$ Current Affiliation: Department of Agricultural and Biosystems Engineering, College of Engineering \\ ${ }^{\mathrm{c} C u r r e n t}$ Affiliation: Department of Electrical Engineering, College of Engineering \\ ${ }^{\mathrm{d} C}$ Current Affiliation: Department of Biological Sciences, College of Arts and Sciences \\ ${ }^{\bullet}$ Corresponding author email: jtmadigal@mmsu.edu.ph
}

\begin{abstract}
The ultimate goal of the present study was to develop a secure, safe, and hygienic nipa sap collection system for bioethanol production, with the aim of preserving its physico-chemical properties such as physical appearance, $\mathrm{pH}$ and sugar brix by reducing the rate of fermentation while attached to the peduncle. The developed collection system was evaluated in terms of the physical and chemical properties of nipa sap collected and ethanol yield in comparison to the traditional and existing collection system used by the nipa community which utilizes bamboo shingle as their collector. Physical appearance of the sap collected using the designed collection system had no foreign materials after harvesting while the traditional collection system had shown traces of insect infestation. The sap that was produced for both of the designed and traditional collection system was milky-white and yellowish-white in color respectively. There was a significant difference in terms of $\mathrm{pH}$ concentration of the sap collected using the designed collection system compared to the sap collected using the traditional system overtime. Sugar brix of nipa sap collected using designed collection system is significantly higher than the sap collected using traditional system. A total ethanol yield of $32.25 \%$ and 75.54\% was obtained for the designed and traditional collection system respectively. Cost Analysis revealed that the designed collection system was found to be cheaper (PhP 11.93) than the traditional collection system (PhP. 20.00). The developed closed collection system can preserved the chemical properties of the nipa sap and could prevent acceleration of fermentation and the deterioration of its potential to yield more ethanol.
\end{abstract}

Keywords: nipa sap, bioethanol, designed collection system, bamboo shingle

\section{INTRODUCTION}

Coping with the fast-evolving world, petroleum-based products were innovations that aided in development and modernization. Petroleum-based products became a key component for engines for the purpose of mobility and transport. The establishment of engine vehicles served as a vital tool for human for transportation to reduce the travel time from one place to another. However, as time progress, the adverse effects of petroleumbased products to the environment are now manifested by the sudden climate changes.

In order to address these, measures were done by the Philippine government to alleviate the problem. One is the establishment of laws addressing the problem on the dependence of the country on imported fuels or the Republic Act No. 9367 (RA 9367) also known as Biofuels Act of 2006. Data from the Philippines energy department (2016) revealed that the net import on oil burst into nearly a third brought about by higher demand in terms of volume and cost of import. From a $\$ 6.89$ billion in 2016, it swelled up into $\$ 9.92$ billion in 2017 resulting in 29.5 percent increase in oil imports of the country. The RA 9367 aims maximize the possibilities of sustainable source of energy, consistently expanding the opportunities in the countryside to aid in the economic growth of the country without risking the natural balance of the ecosystem and the public health. (MMSU, 2018). Thus, a community-based bioethanol production was established in Pamplona, Cagayan. The Mariano Marcos State University (MMSU), as the main proponent of the program, uses Nypa fruticans sap as its feedstock. The local Nipa Plantation supported the National Greening program of the Department of Environment and Natural Resources (DENR).

Among other fuel crops in the country, nipa (Nypa fruticans) palm has the highest potential to be a sustainable feedstock for bioethanol production compared to other fuel crops such as sugarcane and sweet sorghum. Owing its key advantage such as continuous production of sap, low consumption of land and water resources, low in maintenance, and agroforestry among other fuel crops. Additionally, using nipa sap as a substrate may lead to big savings on the production cost for bioethanol. Labor cost for sap collection and hauling to the processing site accounts $46.83 \%$ while electricity and fuelwood require about 
$11.14 \%$ of the total cost compared to other feedstocks such as sugarcane and sweet sorghum (Agrupis et al., 2015). These results show that a village-scale production of bioethanol is economically viable using the fermentation and distillation protocols developed by MMSU. A village- scale ethanol industry using nipa sap is projected to spur real inclusive growth and sustainable development in the community by using high grade ethanol produced for other higher end ethanol applications. The productivity of the nipa plant would be one of the main advantages of the plant among other fuel crops. There is no displaced labor in nipa ecosystem in comparison to sugarcane ecosystem where they need to be harvested first before the saps are extracted (Hidayat, 2015). In terms of land and water resources, competition against other agricultural crops is relatively low. Nipa plants can grow in areas where crops cannot thrive (Tsuji, 2011). Similarly, maintenance of the nipa palm is low because it does not require intensive care and fertilizers. Once matured, they could be tapped for 50 years (Hidayat, 2015). Additionally, the production of nipa is not disrupted by replanting and rotation (Tsuji, 2011). In terms of agroforestry, it could be used as system for habitat conservation such as aquasilviculture designed to rehabilitate fishponds where fishery and nipa production complement each other (Hamilton et al., 1988).

Traditionally, nipa sap is used to make vinegar or local wine through fermentation. Besides its traditional uses, nipa sap is currently the focus of attention as a feedstock for bioethanol (Matsui et al., 2011; Tsuji et al., 2011; Tamunaidu et al., 2013) on the basis of the finding that nipa could produce a higher amount of bioethanol than sugarcane and cassava and at a lower cost. In 2015, Hidayat assessed the natural sap production potential of nipa palms to be processed into bioethanol according to its abundance in South Sumatra. Abundance studies were carried out to evaluate its individual amount and the total of panicles as based for the quantity assessment of nipa sap production. According to the paper, nipa bioethanol production generates higher yield in comparison with other crops, such as sugarcane, cassava, coconut and potato. This potential is relevant with the national program on the development of new and renewable energy to meet the growing energy demand. In this generalization, the study showed the potential natural production of nipa sap ranged from 109.45 to $437.86 \mathrm{~L} \mathrm{ha}^{-1}$ day $^{-1}$ in 2013 . For further processing, nipa sap generating $8.98 \%$ to $14 \%$ of ethanol would then result in bioethanol ranging from 9.83 to $61.3 \mathrm{~L} \mathrm{ha}^{-1}$ day $^{-1}$ or $3,587.92$ to $22,374.54 \mathrm{~L} \mathrm{ha}^{-1}$ year $^{-1}$. Therefore, ethanol produced from nipa saps could be more sustainable than conventional sugar and starch feedstock that are currently available in the market.

Problems arise in the mode of harvesting the sap of a nipa palm specifically in the handling of harvested nipa sap. The deterioration of the quality of the harvested nipa sap was observed during the time of harvesting, by its handling and collection. In MMSU nipa plantation, the collecting tool used is the traditional bamboo shingle. Hypothetically, the researchers posited that there could be a possible effect between the bamboo and the sap during collection that would restrict for a better ethanol yield since bamboo shingle is an organic material and the principle of anaerobic respiration is not considered to affect the end product. Additionally, the sap is exposed in the environment which affects proper fermentation of the sap. Hence, a design for a nipa sap collector was developed, aiming to improve the practice of nipa sap collection and minimize the deterioration of sap in the plantation through restricting the exposure to the external environment.

The present study aimed to design a nipa sap collection system applicable in the local nipa plantation area which could facilitate a better understanding on the effects of a closed collection system and improve the collection practice in the ethanol production site. Specifically, the study aimed to: (1) design a secure and closed collection system and compare it to the traditional (bamboo shingle) collection system; (2) evaluate and compare the physical and chemical properties of the sap collected in the two collection system in terms of $\mathrm{pH}$, sugar concentration (brix), and ethanol yield (\%); and (3) compare the cost of the materials of the two systems and determine the more economical mode of collection. 


\section{METHODS}

\section{Process Flow of Ethanol Extraction from Nipa Sap Collection to Distillation}

Figure 1 shows the complete process of ethanol extraction from cutting of the fruit from nipa up to distillation. Initially, a pre- treatment process was applied by kicking, beating or patting of the peduncle. Immediately after the pretreatment, scraping thin slices right under the fruit across the peduncle is continually performed until the sap flows, followed by placing the collector in a $24 \mathrm{~h}$ period of collection. However, scraping a thin slice from the top of the open peduncle is done in an interval of every 12 hours during the collection. After a $24 \mathrm{~h}$ period is done, the sap is harvested for fermentation. During fermentation, $\mathrm{CO}_{2}$ gas is released as a by-product through oxidation. After fermentation, the fermented sap is subjected to reflux distillation for the ethanol extraction.

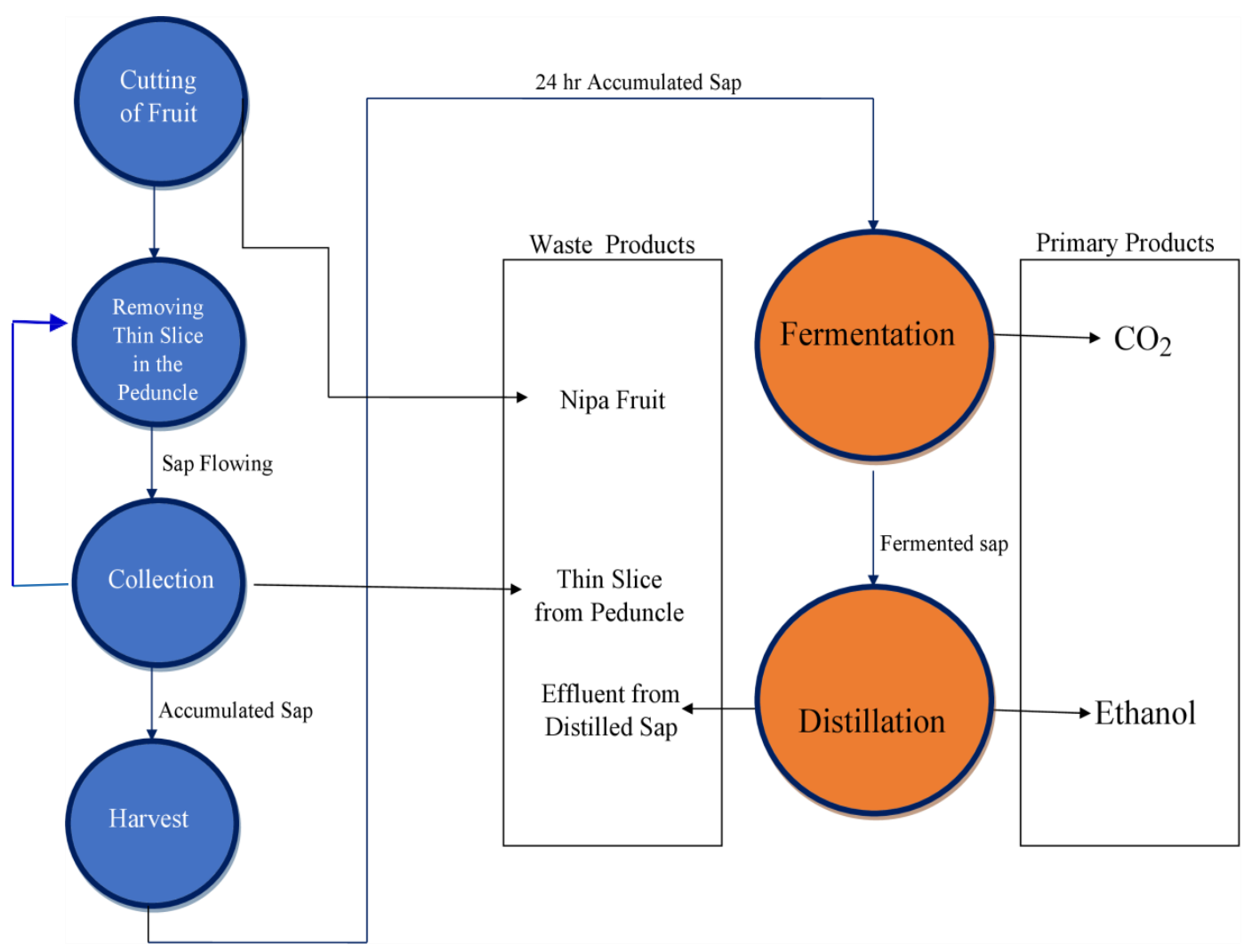

Figure 1. Process Flow of Sap to Ethanol Conversion of the Study

\section{Experimental Location}

The developed closed nipa sap collection system was tested in the community-based nipa plantation of MMSU in Barangay Cabaggan in Pamplona Cagayan (Figure 2) at $18^{\circ} 29^{\prime} 46.5^{\prime \prime} \mathrm{N}$ $121^{\circ} 20^{\prime} 43.4^{\prime \prime E}$. The Nipa palm were selected randomly.

\section{Design and Construction of the Collection System}

The physical body design of the output in this study was designed using AutoCAD 2016. The built of the equipment is made entirely of PET bottles including balloon for the breather and enclosure for the orifice with rubber band holder. Food grade adhesives were used. The materials and accessories that were used in the study were 1.5- and 330-ml liter PET bottles, Latex Balloons and Silicon sealant and flat iron and hand drill.

\section{Testing Procedure}

For the testing procedure, pre-testing and post-testing was done. For the pre-test, the functionality of the collector was strictly checked for leakage. It was done through filling every unit with water then observing for several minutes for dripping water. For the post-testing, it was subjected to a field testing. The key element should be anaerobic, it should not be exposed to the external environment and human interaction to achieve better sap quality. 
Leakage was also checked to avoid losses during harvesting through strict observation for several minutes for the presence of sap dripping. After the PET sap collector has met this initial requirement, evaluation in the field was done.

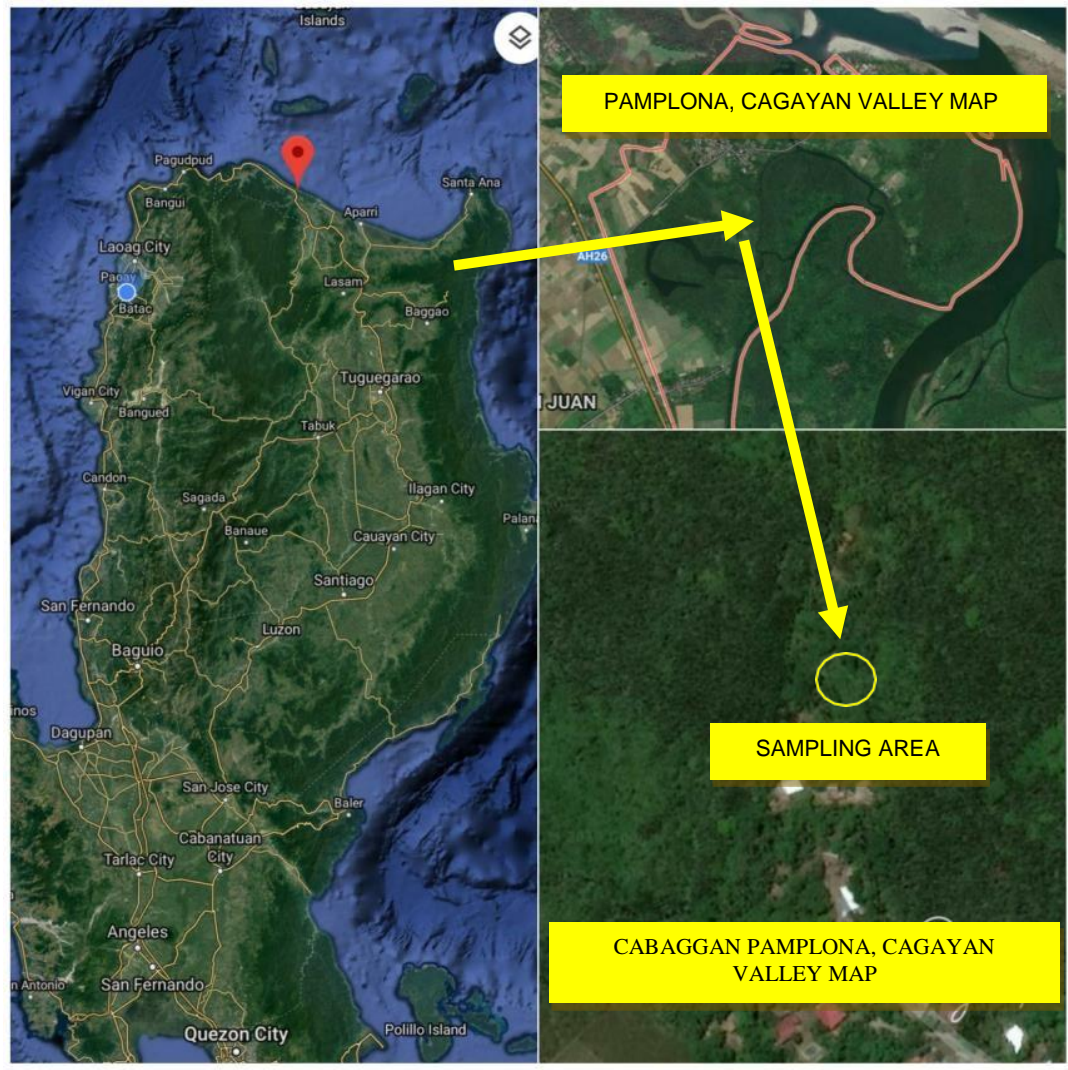

Figure 2. Sampling Area

\section{Data Gathering Procedure}

In this study to evaluate the performance of the equipment, the parameters that were measured in the sap are sugar brix, $\mathrm{pH}$ of the sap, and ethanol yield. A brix hand refractometer was used to determine sugar brix of the collected sap. The $\mathrm{pH}$ of the sap was measured through a $\mathrm{pH}$ meter. The $\mathrm{pH}$ and sugar brix of the sap were measured every $12 \mathrm{~h}$ interval, the initial ( 0 hours) sugar brix and sap were monitored in every $12 \mathrm{~h}$ interval. And the percent ethanol yield was calculated with the formula:

$\%$ yield $=+\frac{\text { actual yield }}{\text { theoretical yield }}(100 \%)$

Where:

- Theoretical ethanol yield was the $8 \% \mathrm{v} / \mathrm{v}$ ethanol yield depending on the volume of the collected nipa sap

- Actual ethanol yield was the amount of actual distilled ethanol by reflux

The parameters mentioned above were immediately quantified after harvesting the nipa sap. All experiments were done in triplicate.

\section{Statistical Analysis}

For the data analysis, one-way analysis of variance was employed to determine if there is a significant difference between the traditional/existing collection methods in the nipa communities with the output system in the study.

The following parameters that were evaluated using one-way analysis of variance in the study were:

- Sap Quality

Pertains to the physical quality of the sap. It was evaluated based on the level of contaminants of the sap and were compared with the traditional system.

- Sap Yield

For the sap yield, it was measured with volume of the collected sap from of the output of this study and was compared with the traditional system.

- Sugar Brix

The sugar brix was measured through the use of brix hand refractometer. 
- $p H$ of the Sap

The $\mathrm{pH}$ of the sap was measured through a portable $\mathrm{pH}$ meter.

- Percent Ethanol Yield

Percent ethanol yield was measured with the formula:

$\%$ yield $=($ actual ethanol yield/theoretical

ethanol yield) $* 100$

distillation system.

\section{Cost of Materials}

The cost of materials was determined by adding all cost incurred that are directly related to the materials needed during sap collection.

\section{Parts and Operation of the Sap Collector}

The developed nipa sap collecting equipment is designed primarily for local nipa plantations. The purpose of this device is to minimize the interaction of the sap from the external environment.

A single unit of the equipment can accommodate one (1) peduncle. As shown in Figure 3. There are 3 primary parts of the equipment. The first part is the 1.5 PET bottle which serves as the collecting chamber of the sap during collection. The second part is the cut corrugated Pet bottle 2 inches diameter with custom-cut latex balloon which serves as an orifice of the peduncle. Lastly, the third part is the 12 inch-sized balloon with random holes which serves as a breather in anaerobic respiration.

\section{RESULTS AND DISCUSSSIONS}

The figures below are the design of the developed collection system used in this study. Figures 3 is the side view and isometric view of the developed design, respectively. In the Figure 3, it shows the design of the collector in the selection of the measurement of the orifice, the peduncle of the nipa palm was considered because of the differences in diameter. The 2 inches diameter was selected because in the site, no nipa sap was able to grow a peduncle with the maximum of 2 inches. To provide, security and attachment to a peduncle, a custom cut balloon was also attached to the orifice and also to minimize the sap exposure. Additionally, a 1.5 PET bottle was used as a collector because its ability to hold the maximum sap yield in the site. The 12 inch size balloon was used to provide exit for the release of carbon dioxide during fermentation and indicator of fermentation activity through its inflation and deflation activity.

In the present study, the physical and chemical properties of the harvested nipa sap were observed and compared between the two different types of sap collector. Figure 4 shows the fabricated sap collection container with labeled parts. The primary built of the designed collection system is based in PET material which does not affect the physical appearance of the sap based on the figure.

\section{Physical Properties of the Collected Sap using Designed and Traditional Collection Systems}

During the data collection of the study, it was observed that the sap collected from the bamboo has already begun producing effervescence and had solid build up in the walls of the bamboo shingle collector. The designed collector method had small amount of effervescence.

The presence of effervescence was more noticeable after harvesting the sap when they were put in the fermentation container. It was observed that the sap collected using the designed collection system became more active in fermentation due to the increased amount of effervescence in the container, contrary to the bamboo shingle collector where its effervescence gradually decreased. It was also observed that the sap collected using the developed collector had a milky- white color during fermentation while the sap using bamboo shingle had a yellowish- white color. Based on the observation of the researchers, the main reason for their difference in color was due to their difference in the type of material for the collector. For the sap collected using a PET type material, it had a cleaner sap because of its inability to react with the acidity of the sap. The bamboo material used to collect sap, reacted with the sap due to its organic properties that react with acidic property of the sap. According to Chen et al., 2011, moisture absorption is a natural phenomenon for natural fibers such as bamboo because of its hydrophilic properties. Because of this, inorganic materials have the tendency to be susceptible for degration (Sailer, 2005). 


\section{Design of Collector}

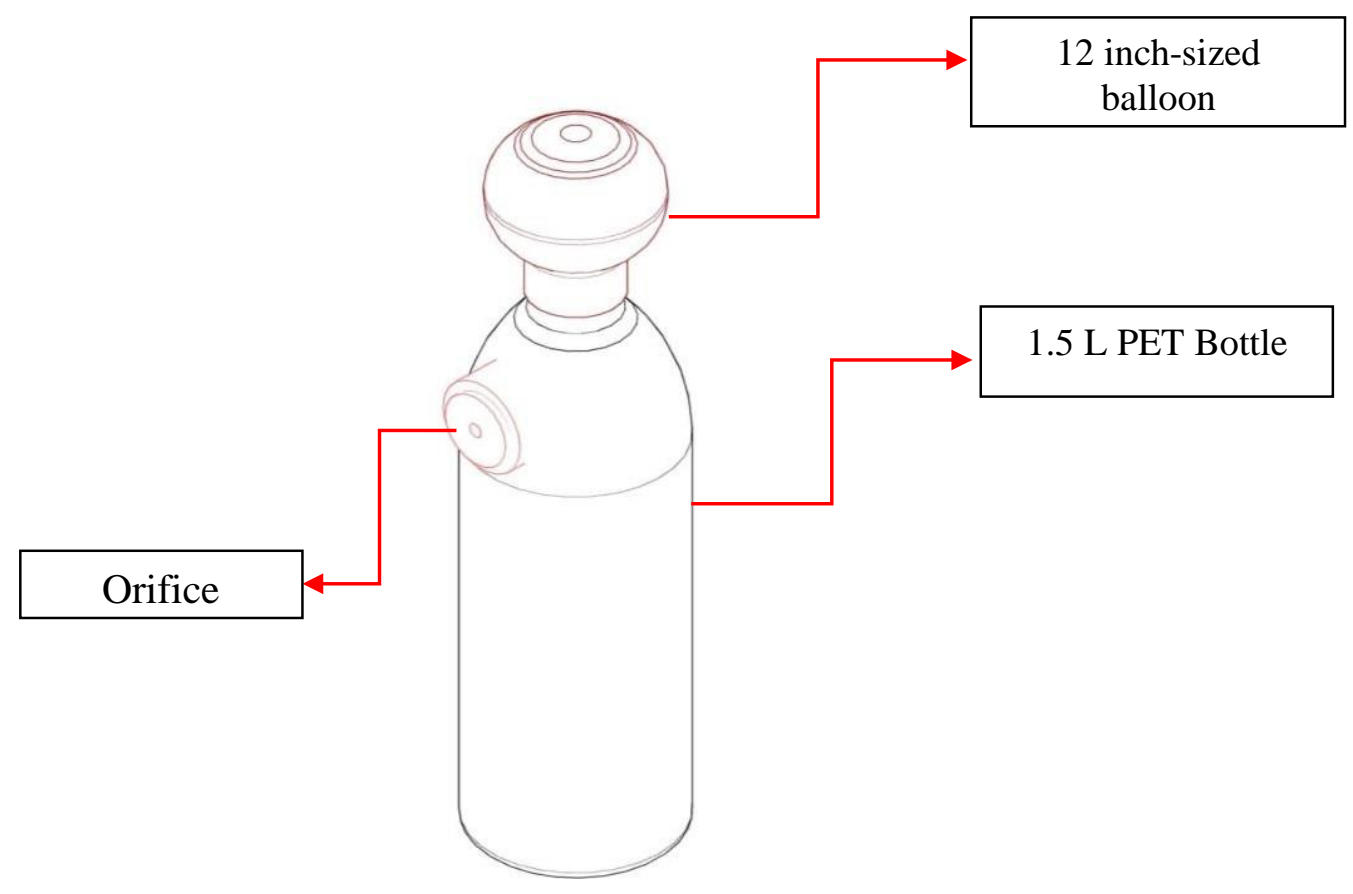

Figure 3. Isometric View of the Designed Collection System

\section{Comparison of sap pH collected using two collection systems}

Table 1 reveals the mean $\mathrm{pH}$ concentration of the collected nipa sap at every after 12 hour observation time using the two collection systems. Analysis shows a high significant difference between the sap collected from the designed collection system and the traditional collection system. Noticeably, $\mathrm{pH}$ of the sap gradually decreasing as time passes. Hence, time affects the decrease of $\mathrm{pH}$ for both of the methods used in the collection. The process of fermentation is responsible for the changes in properties of the nipa sap (Radi, 2013). Another study suggests also supported that the changes of the $\mathrm{pH}$ of the sap from neutral to acidic was the result of the conversion of sugars into ethanol (Saka et al., 2016). Due to this, further fermentation of the sap by acetic acid bacteria would result in the production of vinegar.

Hence, the gradual decrease in $\mathrm{pH}$ value will always be experienced since vinegarhas an acidic $\mathrm{pH}$. The indication of the decrease in $\mathrm{pH}$ is manifested by fermentation which is an important process in producing alcohol for ethanol production.

Table 1. Mean $\mathrm{pH}$ concentration of the sap harvested using the two collection systems in every after $12 \mathrm{~h}$ observation time.

\begin{tabular}{|c|c|c|c|c|c|}
\hline \multirow{3}{*}{$\begin{array}{c}\text { Collection } \\
\text { System }\end{array}$} & \multicolumn{5}{|c|}{ Observation Time, $\mathrm{H}$} \\
\hline & $12 \mathrm{~h}$ & $24 \mathrm{~h}$ & $36 \mathrm{~h}$ & $48 \mathrm{~h}$ & $60 \mathrm{~h}$ \\
\hline & $* *$ & $* *$ & $* *$ & $* *$ & $* *$ \\
\hline Traditional & $3.72^{\mathrm{b}}$ & $3.29^{b}$ & $3.79^{\mathrm{b}}$ & $3.20^{\mathrm{b}}$ & $3.15^{\mathrm{b}}$ \\
\hline Designed & $3.97^{\mathrm{a}}$ & $3.79^{\mathrm{a}}$ & $3.55^{\mathrm{a}}$ & $3.38^{\mathrm{a}}$ & $3.25^{\mathrm{a}}$ \\
\hline $\mathrm{CV}(\%)$ & 3.40 & 3.10 & 3.38 & 3.06 & 2.61 \\
\hline
\end{tabular}

**- Significant at $1 \%$ level

In a column, means marked with the same letter are significantly different at $5 \%$ level using Honestly Significance Difference (HSD) Test. 


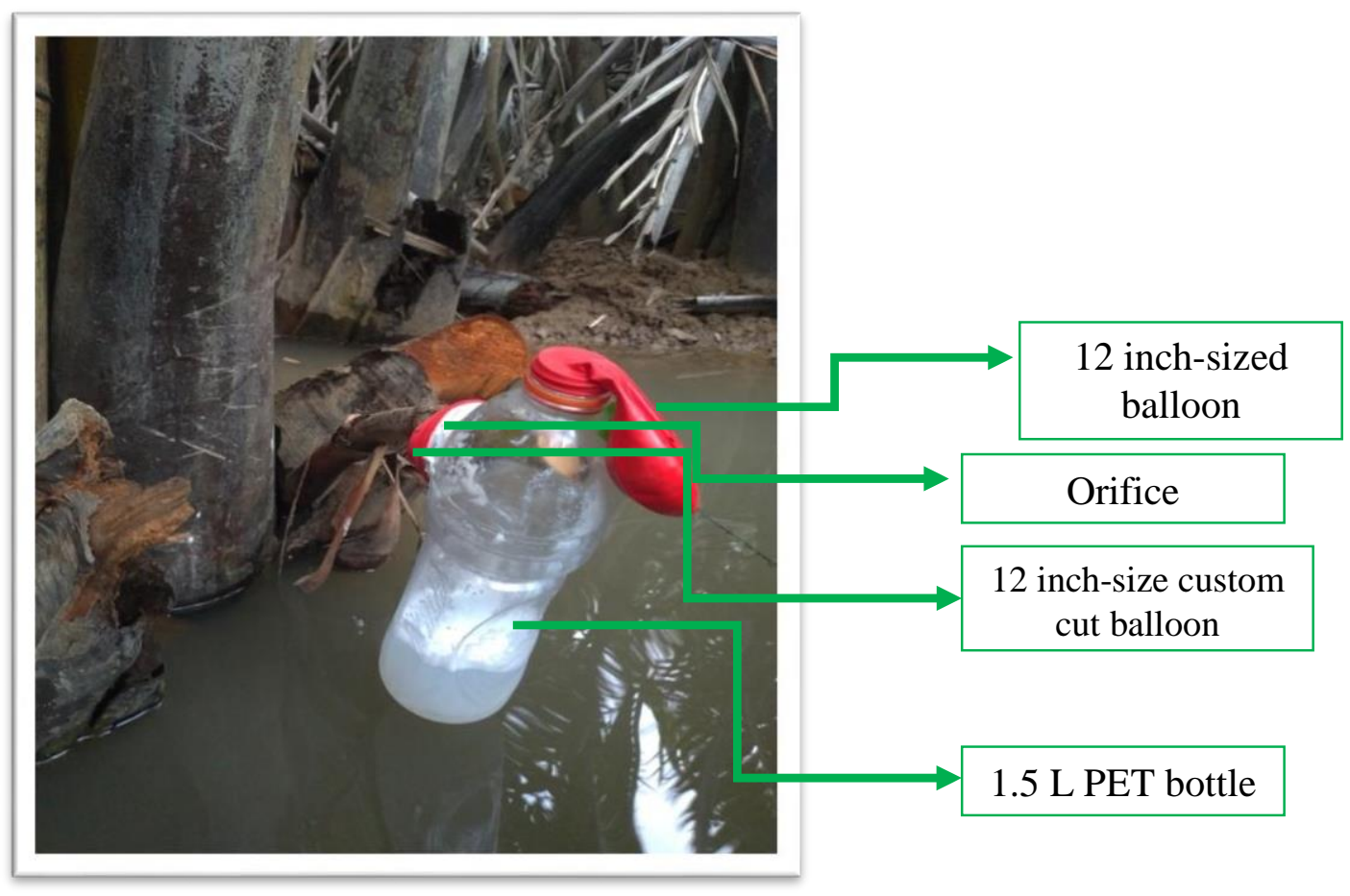

Figure 4. Actual Designed Closed Collection System

\section{Comparison of sap brix collected using two collections systems}

In Tables 2, it can be observed that the sugar brix of both collecting methods as time increases, gradually decreases over time similar to the $\mathrm{pH}$ levels. It can be inferred that the developed collection method significantly showed a higher sugar concentration. For the bamboo collecting device, the sugar content range at 48 hours was 5-6\%. On the other hand, the sugar content of the designed Table 2. Mean sugar brix $\left({ }^{\circ}\right)$ of the sap harvested using the two collection systems in every after 12 hours observation time.

\begin{tabular}{|c|c|c|c|c|c|}
\hline \multirow{3}{*}{$\begin{array}{l}\text { Collection } \\
\text { System }\end{array}$} & \multicolumn{3}{|c|}{ Observation Time (h) } & \multirow{3}{*}{$\begin{array}{c}\mathbf{4 8 ~ h} \\
* *\end{array}$} & \multirow{3}{*}{$\begin{array}{c}\mathbf{6 0} \mathbf{h} \\
* *\end{array}$} \\
\hline & $12 \mathrm{~h}$ & $24 \mathrm{~h}$ & $36 \mathrm{~h}$ & & \\
\hline & $* *$ & $* *$ & $* *$ & & \\
\hline Traditional & $13.07^{b}$ & $8.73^{b}$ & $6.07^{b}$ & $5.40^{\mathrm{b}}$ & $12.33^{b}$ \\
\hline Designed & $16.73^{\mathrm{a}}$ & $16.07^{\mathrm{a}}$ & $15.67^{\mathrm{a}}$ & $13.07^{\mathrm{a}}$ & $5.27^{\mathrm{a}}$ \\
\hline $\mathrm{CV}(\%)$ & 7.60 & 6.07 & 7.01 & 11.67 & 11.42 \\
\hline
\end{tabular}

**-Significant at $1 \%$ level

In a column, means marked with the same letter are significantly different at 5\% level using Honestly Significance Difference (HSD) Test.

Saka et al., 2016 stated that to preserve the chemical composition of the fresh nipa sap, container should be covered. As a result, the sap that are collected using the design in this study had a slower rate in the decrease of sugar concentration because of the effect of designing the collection system as a closed system. In the designed system, it slowed down the process of fermentation during collection. collecting device had a sugar concentration range of $10-15 \%$. To preserve the quality of the sap and avoid deterioration, the present study stated that an alternative would be to cover the containers of the sap to control the acceleration of fermentation. Data suggests that the designed collection system could minimize the changes in the chemical properties of the sap compared to the traditional system because it was designed to be a closed and secure system. 
bamboo shingles that were used. Some bamboo shingles cannot fully contain the amount of sap produced by each peduncle. Unlike in the designed system, it can contain a maximum amount of 1.3 Liters of sap. It was also observed that rodents usually infest the bamboo shingle collector, drinking directly from the cut nipa peduncle. Hence, it is also affecting the sap yield of the peduncle.

One of the factors that was stated by Saka et al., 2016 that affects the sap yield was the age of the nipa palm. Their study stated that middle-aged palm gives the best sap yield. Since the study did not consider the age of palms, there could be a possible effect of the palm age because nipa samples were selected at random. The grown fruit stalks having thicker and longer dimensions also affects the sap yield (Matsui, et al., 2014). Based on the scope of the study, the morphology and physiology of the nipa sap was not considered. Hence, such claim needs further verification.

Table 3. Total mean sap yield collected using the two collection systems.

Collection System

Traditional System

Designed System

$\mathrm{CV}(\%)$

\section{Total Mean Sap Yield, L/Day}

$0.462^{\mathrm{b}}$

$0.865^{\mathrm{a}}$

In a column, means marked with the same letter are significantly different at 5\% level using Honestly Significance Difference (HSD) Test.

The saps were subjected to distillation to determine the percent ethanol yield of both traditional and designed collecting systems as shown in Table 4. For the traditional collection system, an actual ethanol yield of $419 \mathrm{ml}$ of ethanol was obtained resulting into ethanol yield of $75.52 \%$. In the designed collection system, an actual ethanol yield of $258 \mathrm{ml}$ of ethanol resulting into an ethanol yield of 32.25 $\%$. The low ethanol yield of the designed system was due to the fact that the sap collected from the designed collection system has not yet undergone total fermentation due to following the process anaerobic respiration by establishing a closed system. The fresh nipa sap can produce a lower amount of ethanol as compared to the fermented sap (Radi et al., 2013). This shows that there is a lower amount of ethanol yield in the fresh sap in comparison to the fermented sap because it has not yet undergone total fermentation as manifested by their high sugar content. Thus, for the sap collected in the designed system, the potential of it to undergo further fermentation is still likely to happen. Therefore, the collected sap from the designed collection system was able to preserve the chemical properties of the sap. As suggested by Saka et al., 2016, that putting a cover to the container could prevent acceleration of fermentation and the deterioration of its potential to yield more ethanol.

Table 4. Percent ethanol yield of the collected sap from the two collection systems.

\begin{tabular}{cccc}
\hline Collection System & $\begin{array}{c}\text { Actual Ethanol Yield } \\
(\mathbf{m l})\end{array}$ & $\begin{array}{c}\text { Theoretical Ethanol } \\
\text { Yield } \\
(\mathbf{m l})\end{array}$ & $\begin{array}{c}\text { Ethanol Yield } \\
(\mathbf{\%})\end{array}$ \\
\hline Traditional System & 419 & 554.8 & 75.52 \\
Designed System & 258 & 800 & 32.25 \\
\hline
\end{tabular}

\section{Cost of Materials}

Based on the simple calculation of all the cost incurred and dividing it with the total number of units produced, it was computed that the cost per unit of the collecting system was $\mathrm{PhP} 11.93$ cheaper than the price of a single bamboo shingle which cost $\mathrm{PhP}$ 20.00. The bamboo shingle can only be used for a cycle of 2-3 months of collection in the nipa plantation. The usability of the designed collection system could be for multiple times provided that there are no cracks. 
Table 5. Unit Cost of the Collection Systems

\begin{tabular}{ll}
\hline Collection System & Cost/Unit \\
\hline Traditional System & P 20.00 \\
Designed System & P 11.93 \\
\hline
\end{tabular}

\section{CONCLUSIONS}

The development of closed collection system with the aim of improving the practice of nipa sap collection and minimize the deterioration of sap in the plantation through restricting the exposure to the external environment was done. Cleaner sap was observed to the designed closed collection system. The rate of decrease in terms of the $\mathrm{pH}$ and sugar brix for the designed collection system was slower than the traditional collecting system because of its design as closed collection system which made an impact to the preservation of its chemical property by slowing down the process of fermentation. Ethanol yield was observed to be higher in the traditional collection system compared to the designed collection system. This is due to the fact that the sap collected using the designed collection system has not yet undergone total fermentation due to following the process anaerobic respiration by establishing a closed system. Cost analysis showed that the designed system was determined to be relatively cheaper than the traditional collection system.

\section{ACKNOWLEDGEMENTS}

The authors would like to thank National Bioenergy Research and Innovation Center (NBERIC) for the financial assistantship. Also, the authors would like thank Nipa growers and farmers in Pamplona, Cagayan who exerted their time in assisting the researchers during the field trial and experimentation.

\section{REFERENCES}

Agrupis, SC, Birginias, MC, Cocson, AR, \& Abenes, FB. 2015. Potential of Nipa (Nypa fruticans) as Feedstock for Village-Scale Bioethanol Production. Mariano Marcos State University, City of Batac, Ilocos Norte. 2015 In- House Review. ILAARDEC.

Chen H, Miao M, \& Ding X. 2011. Chemical Treatments of Bamboo to Modify Its Moisture Absorption and Adhesion to Vinyl Ester Resin in Humid
Environment. 1533-1542.

Hamilton, LS \& Murphy, DH. 1988. Use and management of nipa palm (Nypa fruticans, Arecaceae): A review. Econ Bot.; 42(2): 206-13.

Hidayat, IW. 2015. Natural production potency of nipa (Nypa fruticans) sap as production commodity for bioethanol. Pros. Sem. Nas. Masy. Biodiv. Indon. 1(1): 109-13.

http://dx.doi.org/10.13057/psnmbi/m010 118

(MMSU) Mariano Marcos State University. (2018, February 06). Retrieved December 30, 2018, from www.mmsu.edu.ph/news/solon-askmmsu-to-help-minimize- importation-offuel-oils

Matsui N, Okimori Y, Takahashi F, Matsumura K, \& Bamroongrugsa N. 2014. Nipa (Nypa fruticans Wurmb) Sap Collection in Southern Thailand. http://dx.doi.org/10.5539/enrr.v4n4p 75

Matsui N, Bamroongrugsa N, Morimune K, Miyasaka H, \& Okimori Y. 2011. Nipa palm: A potential alternative source for bioethanol. Research Paper 14th Mangrove National Seminar [Thai], 319324.

Radi NA. 2013. Physico-Chemical and Microbiological Changes during Fermentation and Storage of Nipa Sap (Nypa fruticans Wurmb). Master Thesis, Universiti Putra, Malaysia.

Sailer MF. 2005. Modelling the Moisture Induce Risk of Decay for Treated and Untreated Wood above Ground, Saxion University of Applied Sciences. https://doi.org/10.1515/HF.2000.019

Saka S, Nguyen DV, Harifara, \& Rabemanolontso A. 2016. Sap from Various Palms as Renewable Energy Source for Bioethanol Production. 355373. 
Tamunaidu, P, Matsui, N, Okimori, Y, \& Saka,

S. 2013. Nipa (Nipa fruticans) sap as a potential feedstock for ethanol production. Biomass and Bioenergy, 52,96-102.

http://hdl.handle.net/2433/174338

Tsuji K, Ghazalli MNF, Nordin Z, Khaidizar

MI, Dulloo ME, \& Sebastian LS. 2011. Biological and Ethnobotanical Characteristics of Nipa Palm (Nypa fructicans Wurmb.): A Review. Sains Malays 40 (12): 1407-1412. 